\title{
On the many Ways Europeanization Matters: The Implementation of the Water Reform in Italy (1994-2006)
}

\author{
Alberto Asquer
}

CESIFO WORKIng PAPER No. 2869

CATEGORY 11: INDUSTRIAL ORGANISATION

DECEMBER 2009

\footnotetext{
An electronic version of the paper may be downloaded

- from the SSRN website: Www.SSRN.com

- from the RePEc website: Www.RePEc.org

- from the CESifo website: www.CESifo-group.org/wp
} 


\title{
On the many Ways Europeanization Matters: The Implementation of the Water Reform in Italy (1994-2006)
}

\begin{abstract}
The research agenda of Europeanization is currently highly focused on issued related to what accounts for the 'horizontal' interaction between domestic actors and how these actors make use of stimuli originating from the EU. This paper aims to contribute to this line of inquiry through the case study of the implementation of the 1994 water reform in Italy in the period between 1994 and 2006. The analysis shows the role played by the use of monetary incentives provided by EU funding sources, by changes in the institutional context partially originating from EU factors, and by the rulings of the European Court of Justice.
\end{abstract}

JEL Code: H79, L95, L98.

Keywords: regulatory reform, public policy implementation, Europeanization, water sector, Italy.

\author{
Alberto Asquer \\ Dipartimento di Ricerche Aziendali \\ Faculty of Economics \\ University of Cagliari \\ Viale Fra Ignazio 17 \\ 09123 Cagliari \\ Italy \\ aasquer@unica.it
}




\section{On the many ways Europeanization matters: the implementation of the water reform in Italy (1994-2006).}

1. Introduction.

In about the last decade, the scholarly literature on the relationship between regulatory reform at the domestic level and regulatory policy at the EU level has increasingly centred around the topic of Europeanization (Risse et al., 2001; Börzel, 2002; Olsen, 2002). As highlighted by Levi-Faur (2006), "rules and procedures [...] stand as the core of what is constructed, diffused and institutionalized as the essence of Europeanization. It is therefore reasonable to suggest that regulation and Europeanization advance hand in hand to create an innovative and in some respects unprecedented multilevel system of regulatory governance. $[\ldots]$ there is no doubt that the intersection of regulation and Europeanization creates one of the most intriguing political spaces of our era". In order to understand the relationship between regulation and Europeanization, however, it is necessary to clarify the subject and the aims of Europeanization studies first.

The focus of Europeanization studies gradually shifted over time. Early work in this field conceived mechanisms and outcomes at the European level as explanatory factors of domestic change (Gualini, 2004; Radaelli, 2004). Later ('second generation') Europeanization studies, instead, adopted an 'evolutionary' perspective of domestic institutional change, which originated from a "specific combinations of factors of change involved in triggering specific mechanisms of change, within a broader definition of possible modes of change and of their dynamic co-evolutive relationship" (Gualini, 2004: 15). Current Europeanization studies do not look at Europeanization as a mere 'top-down' influence from the level of formal EU institutions to domestic policies and organizational and individual behaviour. Rather, they conceive Europeanization as a changing context of choice and behaviour, which induces shifts in the presumptions of actors about the problem-solving arenas and in their strategies (Caporaso and Stone Sweet, 2001).

In this 'second generation' meaning, Europeanization can be conceived as the result of 
the intertwining between the domestic and the EU-level politics and policy, rather than as the causal mechanisms that make the domestic policy process dependent on what takes place at the EU level. Gualini (2004: 24) clarifies this point by highlighting that "Europeanization cannot be assumed right away as an explanans of processes of change. Rather, Europeanization is a framework for analysing difference and variation in processes of mutual adaptation and change (and of resistance to change) affected by new patterns of transnationalnational relations: it is actually an explanandum, which puts the explanatory burden on the factors, mechanisms and dynamics of mutual adaptation and change (as well as of resistance to adaptation and change)". In this perspective, Levi-Faur (2006) observe that the effect of Europeanization on the domestic level can be "less direct, less tangible and less critical than many assume".

Following Radaelli (2004), the relationship between regulation and Europeanization can be theorized as an interactive process through which actors at the domestic level develop complex adaptation patterns to stimuli originating from the EU level. At the domestic level, regulatory change does not take place just because of reactions to adaptational pressures from the EU (Börzel and Risse, 2003). Rather, at the domestic level actors "can use Europe in many discretionary ways. They may discursively create impacts. They may draw of Europe as resource without specific pressure from Brussels. They may get entrapped in European discourses and socialization processes that cannot be captured by a narrow notion of impact (Jacquot and Woll 2003; Thatcher 2004)" (Radaelli, 2004: 4). According to this view, the research agenda of Europeanization is currently highly focused on issued related to what accounts for the 'horizontal' interaction between domestic actors (i.e., rather than the 'vertical' relationship between the EU and the domestic policy domain) and how these actors make use of stimuli originating from the EU.

This paper aims to contribute to this line of inquiry through the case study of the implementation of the 1994 water reform in Italy in the period between 1994 and 2006. In 1994, the Italian Parliament passed Act 36/1994, which intended to radically re-regulate the provision of water services in the country. The implementation of Act 36/1994 unfolded over several years, during which by and large sub-national governments resisted transposing the national water legislation and accomplishing implementation tasks, the central government tried to steer (often ineffectively) the course of the water reform implementation, and 
incumbent water operators eventually were able to outmanoeuvre the reform efforts by retaining a dominant position in the reformed water industry. Differently from other regulatory reforms of network industries (e.g., the gas and electricity ones), the water reform was neither triggered nor directly affected by any EU-level policy directive. EU water policies typically address issues of environmental protection, drinkable water, sewage and wastewater treatment standards, and water management, rather than the economic regulation of the provision of water services. Because of this, the case of the implementation of the 1994 water reform in Italy is exemplar of a type of domestic policy cycle (more specifically, of the implementation 'stage') which is not directly affected by EU-level policies, but in which EUlevel factors may come to play an important role in the 'horizontal' interaction between implementers engaged in the domestic policy arena.

The rest of the paper is organised into five parts. Section 2 will describe the research design of this study. Section 3 will provide a short narrative of the episode of the implementation of the water reform in Italy in the period between 1994 and 2006. Section 4 will analyse the water reform implementation episode. Section 5 will discuss the findings, and the last section will draw the conclusions.

\section{The research design.}

The analysis of the 'horizontal' interaction between implementers engaged in a domestic policy arena is conducted following a processual approach. The questions formulated when conducting processual research typically seek to explain both the pattern of a process stream and the outcome of the process under investigation (Pettigrew, 1997: 340). Accordingly, the research questions addressed in this paper are: How was the water reform implemented? How were sub-national governments able to resist the implementation of the water reform? How, instead, was such resistance overcome? How did local governments manage to retain influence on the regulated water industry? Why was not the central government fully able to steer the course of the water reform implementation? Answering these questions is important in order to understand whether and how Europe-level factors are brought to bear into the process dynamics of implementing a regulatory reform at the domestic level. 
In order to tackle these research questions, this paper will extensively draw from processual intellectual resources. A large stock of such resources has been accumulated over time in various scholarly works, including Barzelay and Campbell (2003), Kingdon (1994), and McAdam et al. (2001). Such resources include, in particular, social mechanisms and their concatenations (Hedström and Swedberg, 1998; Gambetta, 1998), as influenced by process design features and institutional context factors. The analysis, moreover, will build on the assumption that decisions are made following the logic of appropriateness (March, 1994; March and Olsen, 1989), for which action depends on actors' understanding of the self (i.e., identities) and of the situation, and on the canons of proper behaviour that should be followed in any particular circumstances.

The application of a processual framework requires the definition of outcomes that provide a focal point to which to 'anchor' the whole investigation (Pettigrew, 1997: 342). The outcomes of the episode of implementing the water reform in Italy have been identified in various changes of the water regulatory regime, which include a change in the regulatory institutions at the sub-national level, the establishment of new regulatory organizations, and the enforcement of new regulatory tools. The implementation of the water reform in Italy resulted, in particular, in the transposition of the national water legislation into 19 regions, in the establishment of the semi-independent central regulatory agency Supervising Committee on the Use of Water Resources (Comitato di Vigilanza sull'Uso delle Risorse Idriche) and of 92 local regulatory agencies (Autorità d'Ambito Territoriale Ottimale or Authorities of the Optimal Territorial Areas, henceforth OTA authorities), and in the award of water concessions to 102 water firms in 67 OTAs which, by 2006 , fully enforced the new regulatory system.

A few additional remarks should be made concerning some specific features of the water policy domain, in particular in the context of the EU. One feature of the water policy domain is that, among the infrastructure industries, the water one is the most difficult to open to competitive forces (Kessides, 2004; Gómez Ibáňez, 2003; Cowan, 1997) because of technical constraints on joint water carriage, high sunk costs, and widespread political sensitivity against the 'commodification' of water (i.e., charging water tariffs in such a way as to fully cover the cost of water service provision plus provide a return to investors). In this respect, the establishment of more market-oriented forms of regulation of water service provision (e.g., franchise allocation and discretionary regulation) may have a limited 
influence on the reconfiguration of the public intervention in the water sector as well as on the conduct and performance of water service delivery firms.

Another feature of the water policy domain in the EU is that, with respect to other infrastructure industries, the water one lacks any formal EU-level policy concerning any liberalization or economic regulation of the sector. Water policies at the EU level, as expressed, for instance, in the 2000 Water Framework Directive, generally focus on the protection, preservation and management of water resources while they are relatively silent about how water infrastructure and service provision should be regulated (i.e., in terms of access, tariffs, and investments). Differently from other infrastructure industries (e.g., electricity and gas), the water sector has not been subject to any specific EU directive concerning the liberalization of service provision. At the EU member state level, then, EU water policy typically triggers domestic policy discourses about water centred around the themes of environmental protection of water resources, water drinking, sewage, and wastewater standards, and water management, rather than reconfiguring water firms' ownership structure and modes of regulation.

Taking into account these features of the water policy domain in the EU, explaining the outcomes of the water reform implementation in Italy is particularly interesting. Given the country's tradition of public ownership of infrastructure, coupled with technical, economic, and political difficulties to open up the water sector to competitive forces and the lack of EUdriven 'push' to liberalise water service provision, we might expect that hardly could more market-oriented forms of regulation of water service provision (e.g., franchise allocation and discretionary regulation) be established in the country. Yet, by and large the implementation of the water reform resulted in the set up of a new regulatory regime in which water firms were awarded water concessions and infrastructure development should be mostly funded by tariffs set in accordance to criteria of full cost recovery and remuneration of capital invested. Explaining how the implementation of the water reform unfolded and, in particular, what role did EU-level factors play in the episode is the analytic focus of this work.

Data on the episode of the implementation of the water reform in Italy have been collected through interviews to informants based in regulatory agencies, central government water firms, and journalists, parliamentary minutes on the making of the water reform, 11 
reports to the Parliaments and other water sector reviews issued by the Supervising Committee on the Use of Water resources between 1996 and 2007, various reports issued by the research centres Proacqua, Astrid, and Utilitatis, proceedings of the yearly conferences 'H2Obiettivo 2000' organised by the water firms' association Federgasacqua (later renamed Federutility from 2005), and articles from the business press Il Sole 24 Ore.

3. The implementation of the water reform in Italy (1994-2006).

The 1994 water reform mainly originated from the need to cope, on the one hand, with increasing demand for improving water service delivery and water quality (partially due to the rising standards set by EU environmental and water directives) and, on the other one, with declining public funds available for upgrading the water infrastructure. The reform contained in Act 36/1994 aimed to tackle these issues by following a few key design features (Citroni et al., 2007). First, in order to reduce the fragmentation of the industry and allow water firms to achieve economies of scale, water services should be comprehensively organised and managed in relatively large territories (the so-called Ambiti Territoriali Ottimali or OTA). Second, in order to better coordinate the stages of the water management cycle, all the segments of water services (that is, water catchment, distribution, sewage, and wastewater treatment) should be managed 'under one roof' by one only water firm. Third, in order to improve the entrepreneurial management of water firms, planning and control functions should be separated by those of operational management and service delivery (the former being assigned to local regulatory authorities and the latter to the water firms). Finally, in order to allow water firms to achieve financial self-sufficiency, water tariffs should cover the full cost of the water services (i.e., including investment depreciation and return to capital invested).

After the water reform came into force, sub-national governments were expected to collaborate in the transposition of the national water legislation to the regional level. Local governments, instead, often withdrew participating to the process, because they claimed that the central government should fill some details concerning the new regulatory system before they could anticipate the consequences of alternative organizational arrangements. In 1996, the Minister of Public Works, Antonio Di Pietro, became concerned that the delay to 
implement the water reform threatened the spending of the 1994-1999 EU Community Support Framework (CSF) funds for infrastructure development. Di Pietro quickly issued the regulation of the new tariff system and summoned the regions to transpose the national water legislation, otherwise he would exercise central government's substitutive powers. Despite the threat, however, the regions progressed slowly in the implementation of the water reform. Both the regions and local governments, however, later speeded up the transposition efforts from 1997 onwards in reaction to two events. In October 1997, the Parliament assigned special funds for an urgent sewage and wastewater treatment investment programme (Act $344 / 1997$, which was intended to comply with 91/271/CE directive) which also ruled that, in those regions which had not transposed the water reform yet, the OTAs equalled the territories of the provinces. In 1998, the central government ruled that the transposition of the water reform was set as a requirement for accessing additional funds of the 2000-2006 CSF for water infrastructure development in the south. Both southern regions, which could benefit from the 2000-2006 CSF, and the central and northern ones speeded up the transposition of the reform first, which was fully achieved by 1999.

After the regions transposed the water reform, local governments were required to establish local regulatory agencies for each OTA (OTA authorities) where to centralise their water planning and control functions. Most of local governments accomplished this task relatively slowly, as they were concerned with preserving the incumbent position of their water firms rather than making the OTA authorities progress towards awarding the water concessions. The award of water concession speeded up only in late 2001, when the Parliament passed Act 448/2001 (Budget Law), which contained, in article 35, a reform of local public services. The reform provided the general rule that local public services of industrial relevance (i.e., infrastructure services) should be contracted out through tender offer competitions. Special provisions, however, applied to the water sector, whose firms could enjoy either an exemption regime (which allowed to extend extant concessions for a period from 3 up to 9 years, provided that certain conditions, like floating the shares of the water firm in the stock exchange, were met) or a transitory regime (which allowed to directly assign the concessions, within 18 months from the passing of the reform, to water firms fully owned by all the local governments included in the OTAs - i.e., by $30^{\text {th }}$ June 2003 ).

A few years later, in September 2003, the government issued another reform of the local 
public services (Legislative Decree No. 269), which originated from the need to prevent an infraction procedure from the EU Commission concerning some provisions of the 2001 reform which contrasted the EU directives on public sector contracts. The 2003 reform restated the general rule that local public services should be assigned through tender offer competitions, but it also specified that local public service concessions could also be directly assigned to mixed public-private ownership companies in which the private partner was chosen through tender offer competitions, or to firms which were fully owned by the public authorities serviced by the same firms, and which were tightly controlled by the public authorities as close as their own divisions (so-called 'in house' water firms, which a pronouncement of the European Court of Justice had ruled as a legitimate way of assigning local public services in the so-called 'Teckal case' in 1999). After the 2003 reform, several OTA authorities started assigning water concessions in accordance to the new rules, in particular to 'in house' water firms, which rapidly become the most popular organizational form for providing water services in the country. As the direct award of concessions to 'in house' firms prevented opening up the water industry to competition, in December 2004 the Minister of the Environment, Altero Matteoli, issued a couple of directives which aimed to limit the award of water concessions to 'in house' water firms and to mixed public-private ownership firms. Most of the OTA authorities, however, disregarded Matteoli's directives and kept awarding the water concessions to mixed ownership or 'in house' firms.

4. Analysing the water reform implementation process.

In order to examine the resistance of sub-national governments to implement the water reform, we can first discuss what kind of behaviour could be expected by sub-national governments which are required to cooperate across government layers in order to implement a policy mandate. The requirement to transpose the national water legislation to the regional level can be characterised as a 'cooperative intergovernmental policy mandate' (May, 1995), because it prescribed the result to obtain while it was largely silent about the means by which sub-national governments were expected to achieve it. As May (1995) argued, sub-national governments which implement a cooperative intergovernmental policy are exposed to various pressures 'from above' (i.e., from the national government which expects the delivery of policy results) and 'from below' (i.e., from local constituencies and target groups which 
require consideration for specific issues). As an effect of these pressures, the implementation of a cooperative intergovernmental policy depends on the presence of at least a modicum of commitment from the side of the implementers, apart from other factors such as technical and financial capacity and inducements for compliance (May, 1995).

Could the regions and local governments be expected to possess a modicum of commitment to transpose the national water legislation to the regional level? One way to answer this question is to take into account the identity of sub-national governments, the ways in which they perceived (or construed) their situation and interpreted their role. Local governments had been traditionally involved in the direct management of water services, a function which they played in accordance to their autonomy provided by the constitution. When the regions called them to collaborate in the transposition of the national water legislation, local governments could understand that transposing the water reform would pave the way for eventually transferring the water planning and control functions from them to the OTA authorities. Little pressure to collaborate in the transposition of the national water legislation originated form the public, which generally regards water policy as a low-salience policy domain - apart from exceptional periods following distressful events (e.g., flooding). Provided this interpretation of local governments' identity features and perception of the situation, we can argue that local governments could consider as appropriate for their role to protect their stakes in the water sector rather than collaborating in implementing a regulatory policy which threatened their institutional prerogatives. The regions, therefore, lacked any collaboration from the side of local governments and could not progress in the transposition of the national water legislation.

The efforts to transpose the water reform intensified from 1997 onwards, however. Both the authoritative definition of the OTAs provided by Act 344/1997 and the design of an incentive mechanisms which linked the assignment of 2000-2006 CSF funds for infrastructure development to the implementation of the water reform played an important role. First, we can consider that local governments could perceive the authoritative definition of the OTAs equalling the provinces as a violation of their autonomy to determine the ways of managing the local water services. As local governments' autonomy was a politically sensitive topic, local governments could find appropriate to consider the transposition of the water reform (which included the definition of the OTA territories) as an issue to include in their political 
agendas. Second, the southern regions of the country could likely understand, according to canons of instrumental rationality (Gambetta, 1998), that they would benefit from additional funds for infrastructure development provided by the 2000-2006 CSF if they accelerated the transposition of the national water legislation. As the southern regions progressed in performing this activity, we can also hypothesize a mechanism of network diffusion (Hedström and Swedberg, 1998) to explain why additional regions (i.e., those located in the centre and the north of the country) formed the belief in the necessity or inevitability to transpose the national water legislation too.

After the regions transposed the national water legislation to the regional level, generally local governments proceeded relatively slowly in establishing the OTA authorities and making them award water concessions. Taking into account local governments' stakes in the local water services, we can consider for them appropriate to resist devolving their planning and control functions and reorganising the local water industries in such a way as to lose their influence on the water firms. We can highlight, moreover, that the OTA authorities did not play any strong volitional role in the establishment of the new regulatory system. In order to explain the OTA authorities' limited influence on the implementation process, we can hypothesise that the efforts which led local governments to establish the OTA authorities were weakly concatenated with the mechanism of actor certification (McAdam et al., 2001). The OTA authorities were not really validated as authoritative actors of the local water regulatory domain and they experienced difficulties in commanding the resources needed to accomplish the assigned tasks (e.g., southern OTA authorities lacked the resources needed to map the installed infrastructure base, an activity which was largely performed by the state-owned agency Sogesid on their behalf). Furthermore, we can also hypothesise that, after creating the OTA authorities, local governments promptly appropriated them (McAdam et al., 2001), with the effect that the OTA authorities were exploited as vehicles to implement local governments' struggle to resist surrendering their control on water management functions. The OTA authorities, in fact, had not been designed as independent local regulatory agencies, and local governments maintained an influence on the decisions of the public officers which they appointed in charge of the OTA authorities. As a result of these two combined mechanisms, the OTA authorities were rather ineffective to fulfil their institutional identity and remained confined to merely execute local governments' decisions. 
The considerations above contribute explaining why the OTA authorities did not award water concessions. In order to explain why, instead, from 2001 onwards the OTA authorities increased the number of water concessions awards, we need to take into account how the making of two local public services reforms in 2001 and 2003 affected the implementation process. This question can receive at least three answers. First, if we take into account that the 2001 local public services reform narrowed the range of option choices for awarding the water concessions, then we can hypothesise that a mechanism of attribution of threats (McAdam et al., 2001) made some local governments speed up the awarding of water concessions before the coming into force of the 2001 reform foreclosed the possibility to assign long-term franchise contracts without calling tender offer competitions. This mechanism would affect, in particular, the efforts of local governments which had committed themselves to reorganise their water services according to an arrangement which would be illegitimate under the new local public services legislation, and which had the possibility, anyway, to finalise it within a few weeks (i.e., in the short period of time between the passing and the coming into force of Act 448/2001 some OTA authorities, in particular in Tuscany, 'rushed' to carry out the water concession award procedure in December 2001).

Second, if we take into account that the 2001 local public services reform provided that the award of water concessions through tender offer competitions could be postponed up to 9 years if certain conditions were met, then we can hypothesise that a mechanism of attribution of opportunities (McAdam et al., 2001) induced some local governments to progress in the award of the water concessions according to the requirements of the transitory regime. This mechanism would affect, in particular, the efforts of local governments which aimed to retain some influence on the management of local water services by making the OTA authorities award the water concessions to local government-owned water firms rather than to firms selected through tender offer competitions. The possibility offered by the transitory regime, however, could be perceived as an opportunity only by local governments which accepted the requirements set by the 2001 local public services reforms for postponing the application of the tender offer competition rule, i.e., to open up the ownership of the water firms to private investors (up to 51\%) and to make the water firms increase in size through the merger with other operators. In the instances of reorganization of the local water services which matched these specific circumstances, as those taking place for example in Emilia Romagna, the deadline for the eligibility for the transitory regime set on $30^{\text {th }}$ June 2003 served as a focusing 
event (Kingdon, 1984) which catalysed local governments' efforts to make the OTA authorities award the water concessions in relatively short time.

Third, if we take into account that the 2003 local public services reform granted the possibility to legitimately award water concessions to mixed public-private ownership and 'in house' water firms rather than to firms selected through tender offer competitions, we can again hypothesise that a mechanism of attribution of opportunity (Mc Adam et al., 2001) triggered several local governments to intensify their efforts to make the OTA authorities award the water concessions in ways that allowed them to retain influence on the management of local water services. This mechanism would affect, in particular, the efforts of local governments which aimed to retain some influence on the management of local water services and which had not progressed in the award of water concessions according to the options available after the 2001 local public services reform. In several instances of reorganization of the local water services all over the country, many local governments exploited the possibility to make the OTA authorities award water concessions to 'in house' water firms.

The analysis above suggests that the making of the 2001 and 2003 local public services reforms played an important role in the dynamics of allocating water franchises. This role can be understood taking into account how local governments made sense of the legislative changes and how the sequencing of the local public services reforms reshaped the terms of the situation for those local governments which had not made the OTA authorities award the water concessions yet. Given these cognitive and situational factors, the mechanism of attribution of opportunities and threats (McAdam et al., 2001), which also coupled with the presence of focusing events (Kingdon, 1984) centred on deadlines for the application of rules, can account for the increase of local governments' efforts in making the OTA authorities award the water concessions. The timing and the content of the 2001 and 2003 local public services reforms, then, can contribute explaining the particular forms of reorganization of the local water services which culminated in the award of water concessions in the few weeks between the passing and the coming into force of the 2001 local public services reform, in the period from the coming into effect of the 2001 local public services reform until $30^{\text {th }}$ June 2003, and after the issue of the 2003 local public services reform.

After the coming into force of the local public services reforms, most of the OTA 
authorities awarded the water concessions to local government fully or majority-owned firms despite the efforts of the Minister of the Environment Altero Matteoli to make them apply the tender offer competition rules. A question arises, then, concerning why Matteoli's efforts were not effective to make the OTA authorities award the water concessions to business companies selected through competition mechanism. One tentative answer to this question is that Matteoli was not able to persuade local governments to accept his policy orientation, which he expressed in two directives issued in December 2004, because the 2003 local public services reform allowed to legitimately award water concessions to mixed public-private ownership and 'in house' firms. Local governments could convincingly bring into play the 1999 ruling of the European Court of Justice (i.e., so-called 'Teckal case') which granted legitimacy to the direct award of local public service concessions to 'in house' firms. In the process of making sense (Weick, 2001; Barzelay and Jacobsen, 2009) of the applicability of formal rules to the award of water concessions, then, local governments' convictions about the legitimacy of awarding water concessions bypassing the tender offer competition rule were firmly rooted in the cues explicitly contained in the European Court of Justice's ruling and in the 2003 legislation.

Matteoli's efforts to affect the awards of water concessions were also undermined by the opposition of the regions. In January 2004, in particular, the region Tuscany appealed to the Constitutional Court against the part of the 2003 local public services reform which provided a detailed regulation of how local public services should be awarded to companies selected through tender offer competitions. In July 2004, the Constitutional Court broadly accepted the appeal on the ground that the 2001 constitutional reform did not explicitly assign to the State the competences on local public services, which were, therefore, devolved to the regions. We can hypothesise, then, that a mechanism of actor de-certification (i.e., "the withdrawal of [such] validation [of actors, their performances, and their claims] by certifying agents", McAdam et al., 2001: 121) dispossessed the Minister of the Environment of competences on regulating water concession awards at the sub-national level. Matteoli's ineffectiveness to affect OTA authorities' decisions, therefore, can be also explained by the role played by the reconfiguration of government functions across the multi-layered system of governance in Italy. 


\section{Discussion.}

Before embarking in the discussion of the process dynamics of implementing the water reform in Italy, we can summarise the main findings which originate from the analysis above. A first finding, which relates to the resistance to transpose the national water legislation, is that the mechanism of the logic of appropriateness initially made sub-national governments, which were traditionally involved in the provision of local public services and which could understand that the implementation of the water reform would lead to centralise water functions away from them, withdraw from collaborating in implementing the water reform. A second finding, which relates to the acceleration of the transposition of the national water legislation, is that sub-national governments increased their efforts to implement the reform because of the effect of hypothesised mechanisms of instrumental rationality (which related to the central government's authoritative definition of the OTAs which contrasted with local governments' autonomy, and to the incentive for sub-national governments located in the southern regions of the country to appropriate additional funds provided by the 2000-2006 CSF) and network diffusion (which propagated collaborative behaviour across the country). Finally, a third finding, which relates to the award of water concessions, is that the acceleration in the enforcement of the new regulatory tools can be explained by the mechanisms of attribution of opportunities and threats (triggered by the 2001 and 2003 local public services reforms) in conjunction with focusing events. The outcome of the process, moreover, is affected by the inability of central government officers to steer the behaviour of implementers because of the lack of persuasion in the process of sense-making relating to the applicability of public contracting rules (related to the European Court of Justice's pronouncement), and because of a mechanism of actor de-certification which delegitimised the central government to regulate the award of water concessions (related to the 2001 constitutional reform).

The study of the case of the implementation of the water reform in Italy has provided significant elements for drawing some tentative theorizations about the dynamics of regulatory reform implementation and the role played by EU-level factors. In the Italian case, various features of initial conditions and context factors hampered the implementation of the water reform by making sub-national governments resist surrendering their influence on local water service provision, but later on obstacles to implement the water reform were eventually 
overcome. The case of the implementation of the water reform in Italy, therefore, includes types of courses of events in which sub-national governments initially resisted to accomplish implementation tasks but later complied with the reform mandate, although in such a way as to retain a significant influence on the reformed water sector despite the efforts of central government officers to steer the allocation of water franchises. In these changes of trajectory, an important role was played by (1) the way in which monetary incentives provided by EU funding sources were employed to stimulate progressing in the water reform implementation, (2) the way in which changes in the institutional context partially originating from EU factors were exploited for preserving the position of incumbent firms in the water sector, and (3) the way in which court rulings at the EU level were brought to bear in order to shield the conduct of sub-national governments from the pressure of central government officers. Theorizations about why and how these changes in trajectory may take place are discussed.

A first tentative statement is that the joint presence of monetary resources which are made available by EU programmes and of the authority to make use of these resources for stimulating the accomplishment of implementation tasks triggers implementers' pursuit of material interests which can lead to collaborating in cascading the regulatory reform at the sub-national level and in establishing new regulatory institutions. In the case of the implementation of the water reform in Italy, monetary resources were made available by the implementation of directive 91/271/CE (Act 344/1997) and of the 1994-1999 and 2000-2006 CSF. The Parliament allocated monetary resources for implementing directive 91/271/CE to authoritatively defined OTAs, and the central government designed an incentive scheme which assigned additional funds for infrastructure development provided that sub-national governments progressed in accomplishing implementation tasks. Sub-national governments reacted to these stimuli by increasing their collaborative efforts in transposing the national water legislation to the regional level and in establishing the OTA authorities. The mechanism of instrumental rationality, in concatenation with those of focusing event and network diffusion, is important for explaining how, after an initial period of resistance, sub-national governments later turned to progressing in the implementation of the water reform.

This tentative statement, however, needs some qualifications. The availability of monetary resources and the authoritative use of these resources for stimulating the efforts of the implementers may be a necessary but not a sufficient condition for progressing in the 
regulatory reform implementation. Another important ingredient seems to be the activation of a mechanism of attribution of threats for mobilising the implementers against the prospect of a loss. It is important, in this respect, the perception of the actual loss or of the likelihood that the threat would materialise in the future if certain conditions are met. In the case of the implementation of the water reform in Italy, for example, the threat conveyed by central government officers that the regions would be commissioned if they defaulted transposing the national water legislation triggered, on the whole, a modest reaction from the side of subnational governments. The authoritative definition of the OTA jurisdictions as equalling the provinces, instead, appeared to local governments as an actual loss of their autonomy and therefore was likely to make them more inclined to act to remedy against the situation.

Another qualification to the above statement is that progression in regulatory reform implementation may be achieved anyway even without any use of monetary incentives. In the case of the implementation of the water reform in Italy, for example, sub-national governments located in Tuscany carried out the transposition of the national water legislation and the establishment of the OTA authorities before the central government made any use of monetary resources for stimulating the accomplishment of implementation tasks. In Tuscany, as well as in other regions, the presence of monetary resources provided by the implementation of directive 91/271/CE and of the 1994-1999 and 2000-2006 CSF did not significantly affect the local trajectory of regulatory reform implementation. It is important, in this respect, to specify that the use of monetary incentives may help to overcome resistance to implement the reform, but also that the presence of monetary incentives is not a necessary feature of successful regulatory reform implementation.

A second statement is that changes in the institutional context partially originating from EU factors, in conjunction with a tradition of direct involvement of sub-national governments in the provision of infrastructure services, triggers the exploitation of opportunities and avoidance of threats which lead sub-national governments to find their way to preserve the position of incumbent sub-national government-owned firms in the infrastructure industry. In the case of the implementation of the water reform in Italy, the 2001 and 2003 local public services reforms provided the possibility for the OTA authorities to award water concessions to local government fully or partially owned water firms. From 2001 onwards, the OTA authorities awarded an increasing number of water concessions over time, mostly to various 
kind of local government fully or partially owned firms. The mechanism of attribution of opportunity (to make the water concession legitimately awarded to incumbents) and threats (that the 'window of opportunity' offered by the rules provided by the local public services reforms might close in the future), in concatenation with focusing event (which centred around the deadline for the coming into force of the 2001 reform and for the expiration of the transitory and exemption regimes), are important for explaining how sub-national governments progressed in the implementation of the water reform while being also able to preserve the position of the incumbent firms in the water industry.

It should be highlighted, however, that the way in which changes in the institutional context are exploited is dependent on the time in which these changes take place with respect to the trajectory of regulatory reform implementation at the local level. In the case of the implementation of the water reform in Italy, for example, local governments made the OTA authorities award the water concessions to different kinds of firms (e.g., mixed public-private ownership firms, local government-owned firms whose shares where traded in the stock exchange, and 'in house' firms) depending on the rules for the allocation of water franchise which were in force at the time. The changes in the institutional context, therefore, are a necessary albeit not sufficient condition for making implementers protect the position of the incumbent firms in the infrastructure industry. Additional conditions must be met, namely the timely restructuring of incumbent firms in order to match the requirements for being allocated the infrastructure franchise, in order for sub-national governments to retain their traditional influence on the local infrastructure services.

Finally, a third statement that can be drawn from the case of the implementation of the water reform in Italy regards the importance of court rulings in making central government's efforts to steer the regulatory reform implementation ineffective to influence the behaviour of implementers. In 2004, the Minister of the Environment Matteoli tried to make sub-national governments award water concessions to business companies selected through tender offer competitions rather than to 'in house' or mixed ownership firms. Sub-national governments effectively counteracted his efforts by appealing to two judicial rulings, namely the European Court of Justice's adjudication of legitimacy of local public service awards to 'in house' water firms (i.e., 'Teckal case') and the Constitutional Court's pronouncement of exclusive competence of the regions on the detailed regulation of local public services after the 2001 
constitutional reform. The mechanisms of sense making (i.e., making sense of which behaviour was legitimate) and actor de-certification (which withdraws the authority away from the central government) are important to explain how sub-national governments succeeded to retain their influence on the local water services in their struggle against the central government.

Also the above statement should bear some qualifications. First, court rulings need to be actively recalled by sub-national governments in order for them to effectively claim that their behaviour, which the central government aims to rectify, is legitimate. In the case of the implementation of the water reform in Italy, for example, local governments counteracted central governments' efforts to make the OTA authorities award water concessions to business companies selected through tender offer competitions by claiming that the assignment of water franchise to 'in house' firms was legitimate according to the European Court of Justice's adjudication (which, incidentally, had been formulated on a quite different matter but water franchise allocation, namely the assignment of local public transport concession). Second, court rulings may need to be solicited by sub-national governments in order to provide the legal protection against central government's claims to regulate their behaviour. In the Italian case, for example, the region Tuscany appealed to the Constitutional Court in order to counteract central government's interference with the regulation of the awards of local public services, which had been reserved as an exclusive competence of the regions by the 2001 constitutional reform. The active role of implementers in bringing into consideration or eliciting court ruling, therefore, seems to be a crucial factor for shielding their behaviour from the efforts of the central government to steer the implementation of the regulatory reform.

\section{Conclusions.}

The study of the case of the implementation of the water reform in Italy has provided some important elements for explaining how EU-level factors are brought to bear in the implementation of regulatory reforms. In broad terms, at least three groups of factors have been identified which affect the dynamics of regulatory reform implementation. A first group concerns the factors that contribute accelerating the implementation of regulatory reforms, such as monetary incentives and the exercise of authority by the central government. A second 
group relates to the factors that allow the target population to 'bend' the implementation of the regulatory reform in such a way as to retain their incumbent positions in the regulated sector. These factors include changes in the institutional context which open up 'windows of opportunity' for the target group to substantively 'hollow out' part of the reform package. Lastly, a third group of factors regards those which prevent the central government from steering the course of the regulatory reform implementation. These factors include court rulings which enforce super-national (e.g., EU) regulations and constitutional changes to cases related to the regulatory reform implementation.

How can we deepen our understanding of the influence of EU-level factors on the dynamics of the policy process at the domestic (i.e., EU member state) level? Several scholars have variously conceived this influence within the frame of reference of Europeanization, which refers to "processes of (a) construction (b) diffusion and (c) institutionalization of formal and informal rules, procedures, policy paradigms, styles, 'ways of doing things' and shared beliefs and norms which are first defined and consolidated in the making of EU public policy and politics and then incorporated in the logic of domestic discourse, identities, political structures and public policies" (Radaelli, 2003). Cowles and Risse (2001) explained domestic change mostly in terms of adaptive reaction to pressures to meet European requirements. Knill and Lehmkuhl $(2002 ; 1999)$ proposed to explain the domestic impact of European policy making with three Europeanization mechanisms, namely institutional compliance, changing the domestic opportunity structures, and framing domestic beliefs and expectations (later partially reframed as mechanisms of coercion, competition, and communication; Knill and Lenschow, 2005). Harcourt (2003) and Radaelli (2003) highlighted the difference between vertical and horizontal mechanisms of Europeanization. Schmidt (2008) placed attention on how negative integration (i.e., market making) and legal uncertainty around European law affect domestic policy making.

The present study further expands 'horizontal' Europeanization research by identifying the social mechanisms which underpin the use of EU-level factors in domestic policy arenas which are not specifically regulated by EU policies (the economic regulation of the water sector providing an instance of such policy arena). The Italian case shows that EU-level factors played an important role in the implementation of the water infrastructure regulatory reform: EU funds for infrastructure development were employed by the central government in 
the design of monetary incentives for stimulating sub-national governments to accomplish implementation tasks, EU directives on environmental regulation and water quality standards were implemented by the central government by authoritatively establishing new water regulatory jurisdictions (i.e., the OTAs), and the rulings of the European Court of Justice were exploited by local governments in order to limit central government's interference on the allocation of water franchises. These instances suggest that domestic policies can be 'Europeanized' through the active use of EU-level factors by domestic actors even in the absence of any EU policy keyed to the specific domain. Research examining how domestic actors bring EU-level factors to bear in the making and implementation of domestic policies, then, is likely to provide further important contributions to the advancement of the study of the Europeanization of regulatory reforms, in infrastructure as well as in other policy areas. 
References:

Barzelay M. and C. Campbell (2003), Preparing for the Future: Strategic Planning in the U.S. Air Force. Washington, DC: Brookings Institution.

Barzelay, M. and Jacobsen, A. S. (2009), “Theorizing Implementation of Public Management Policy Reforms: A Case Study of Strategic Planning and Programming in the European Commission", Governance, 22, 2, pp. 319-334.

Börzel T. A. (2002), "Pace-Setting, Foot-Dragging, and Fence-Sitting: Member State Responses to Europeanization", Journal of Common Market Studies, 40(2):193-214.

Börzel T. A. and T. Risse (2003), "Conceptualising the domestic impact of Europe", in K. Featherstone and C. M. Radaelli (eds), The Politics of Europeanization. Oxford: Oxford University Press, 57-80.

Caporaso J.A. and A. Stone Sweet (2001), "Conclusion: Institutional Logics of European Integration", in A. Stone Sweet, W. Sandholtz, and N. Fliegstein (eds), The Institutionalization of Europe. Oxford: Oxford University Press, 221-36.

Citroni G., N. Giannelli, A. Lippi, and S. Profeti (2007), “Chi governa l'acqua?: regolazione, potere locale, e arene di rappresentanza nella governance del servizio idrico integrato", SISP Conference, Catania, 20-22 September.

Cowan, S. (1997), "Competition in the Water Industry", Oxford Review of Economic Policy, $13,83-92$.

Cowles, M. G., and T. Risse (2001), “Transforming Europe: Conclusions”, in M. G. Colwes, J. A. Caporaso, and T. Risse (eds), Transforming Europe. Europeanization and Domestic Change. Ithaca, NY: Cornell University Press, 217-238.

Gambetta D. (1998), "Concatenations of Mechanisms", in P. Hedström and R. Swedberg (eds.), Social Mechanisms: An Analytic Approach to Social Theory. Cambridge: Cambridge University Press, 102-125.

Gómez Ibáňez J. A. (2003), Regulating Infrastructure: Monopoly, Contracts, and Discretion. Harvard University Press.

Gualini E. (2004), Multi-level Governance and Institutional Change: The Europeanization of Regional Policy in Italy. Ashgate Publishing.

Harcourt A. (2003), "Europeanization as convergence: the regulation of media markets in the European Union", in K. Featherstone and C. M. Radaelli (eds), The Politics of Europeanization. Oxford: Oxford University Press, pp. 179 - 202.

Hedström P. and R. Swedberg (eds.) (1998), Social Mechanisms: An Analytic Approach to Social Theory. Cambridge University Press. 
Jacquot S. and C. Woll (2003), "Usage of European integration: Europeanization from a sociological perspective", European Integration online Papers, 7(12), http://eiop.or.at/ eiop/texte/2003-012a.htm.

Kessides I. N. (2004), Reforming Infrastructure: Privatization, Regulation, and Competition. The World Bank.

Kingdon J. (1984), Agendas, Alternatives, and Public Policies. Boston, MA: Little, Brown.

Knill C. and D. Lehmkuhl (1999), "How European matters: different mechanisms of Europeanization", European Integration online Papers, 3(7), http://eiop.or.at/eiop/texte/1999007.htm.

Knill C. and D. Lehmkuhl (2002), "The national impact of European Union regulatory policy: Three Europeanization mechanisms", European Journal of Political Research, 41(2) March: 255-280.

Knill C. and A. Lenschow (2001), “Adjusting to EU environmental policy: change and persistence of domestic administrations", in M. Green Cowles, J. Caporaso and

T. Risse (eds), Transforming Europe. Europeanization and Domestic Change. Ithaca, NY: Cornell University Press, 116 - 36.

Levi-Faur D. (2006), Regulatory Governance, in P. Graziano and M. Vink (eds), Europeanization: New Research Agendas. Basingstoke: Palgrave Macmillan, ch. 8.

March J. G. (1994), A Primer on Decision Making. New York: Free Press.

March J. G. and J. P. Olsen (1989), Rediscovering Institutions: The Organizational Basis of Politics. New York: Free Press.

May P. J. (1995), "Can Cooperation Be Mandated? Implementing Intergovernmental Environmental Management in New South Wales and New Zealand", Publius: The Journal of Federalism, 25(1): 89-114.

McAdam D., S. Tarrow, and C. Tilly (2001), Dynamics of Contention, Cambridge: Cambridge University Press.

Olsen J. P. (2002), “The many faces of Europeanization”, Journal of Common Market Studies, 40(5): 921-952.

Pettigrew A. M. (1997), "What Is a Processual Analysis?", Scandinavian Journal of Management, 13, 337-348.

Radaelli C. M. (2003), "The Europeanization of public policy”, in K. Featherstone and C. M. Radaelli (eds.), The Politics of Europeanization. Oxford, Oxford University Press: 27-56.

Radaelli C.M. (2004), “The puzzle of regulatory competition”, Journal of Public Policy, 24(1): 1-23. 
Risse T., J. Caporaso, and M. G. Cowles (2001), "Europeanization and Domestic Change. Introduction", in M. Cowles, J. Caporaso and T. Risse (eds.), Transforming Europe: Europeanization and Domestic Change. Ithaca NY: Cornell University Press, 1-20.

Schmidt S. (2008), "Beyond Compliance: The Europeanization of Member States through Negative Integration and Legal Uncertainty", Journal of Comparative Policy Analysis, 10(3): 299-308.

Thatcher M. (2004), "Winners and losers in Europeanisation: Reforming the national regulation of telecommunications", West European Politics, 27(2): 284-309.

Weick K. E. (2001), Making Sense of the Organization. Oxford: Blackwell. 


\section{CESifo Working Paper Series}

for full list see www.cesifo-group.org/wp

(address: Poschingerstr. 5, 81679 Munich, Germany, office@cesifo.de)

2805 Christian Lessmann and Gunther Markwardt, Aid, Growth and Devolution, September 2009

2806 Bas Jacobs and Dirk Schindler, On the Desirability of Taxing Capital Income to Reduce Moral Hazard in Social Insurance, September 2009

2807 Hans Gersbach and Noemi Hummel, Climate Policy and Development, September 2009

2808 David E. Wildasin, Fiscal Competition for Imperfectly-Mobile Labor and Capital: A Comparative Dynamic Analysis, September 2009

2809 Johan Eyckmans and Cathrine Hagem, The European Union's Potential for Strategic Emissions Trading through Minimal Permit Sale Contracts, September 2009

2810 Ruediger Bachmann and Christian Bayer, The Cross-section of Firms over the Business Cycle: New Facts and a DSGE Exploration, October 2009

2811 Slobodan Djajić and Michael S. Michael, Temporary Migration Policies and Welfare of the Host and Source Countries: A Game-Theoretic Approach, October 2009

2812 Devis Geron, Social Security Incidence under Uncertainty Assessing Italian Reforms, October 2009

2813 Max-Stephan Schulze and Nikolaus Wolf, Economic Nationalism and Economic Integration: The Austro-Hungarian Empire in the Late Nineteenth Century, October 2009

2814 Emilia Simeonova, Out of Sight, Out of Mind? The Impact of Natural Disasters on Pregnancy Outcomes, October 2009

2815 Dan Kovenock and Brian Roberson, Non-Partisan 'Get-Out-the-Vote' Efforts and Policy Outcomes, October 2009

2816 Sascha O. Becker, Erik Hornung and Ludger Woessmann, Catch Me If You Can: Education and Catch-up in the Industrial Revolution, October 2009

2817 Horst Raff and Nicolas Schmitt, Imports, Pass-Through, and the Structure of Retail Markets, October 2009

2818 Paul De Grauwe and Daniel Gros, A New Two-Pillar Strategy for the ECB, October 2009

2819 Guglielmo Maria Caporale, Thouraya Hadj Amor and Christophe Rault, International Financial Integration and Real Exchange Rate Long-Run Dynamics in Emerging Countries: Some Panel Evidence, October 2009 
2820 Saša Žiković and Randall K. Filer, Hybrid Historical Simulation VaR and ES: Performance in Developed and Emerging Markets, October 2009

2821 Panu Poutvaara and Andreas Wagener, The Political Economy of Conscription, October 2009

2822 Steinar Holden and Åsa Rosén, Discrimination and Employment Protection, October 2009

2823 David G. Mayes, Banking Crisis Resolution Policy - Lessons from Recent Experience Which elements are needed for robust and efficient crisis resolution?, October 2009

2824 Christoph A. Schaltegger, Frank Somogyi and Jan-Egbert Sturm, Tax Competition and Income Sorting: Evidence from the Zurich Metropolitan Area, October 2009

2825 Natasa Bilkic, Thomas Gries and Margarethe Pilichowski, Stay in School or Start Working? - The Human Capital Investment Decision under Uncertainty and Irreversibility, October 2009

2826 Hartmut Egger and Udo Kreickemeier, Worker-Specific Effects of Globalisation, October 2009

2827 Alexander Fink and Thomas Stratmann, Institutionalized Bailouts and Fiscal Policy: The Consequences of Soft Budget Constraints, October 2009

2828 Wolfgang Ochel and Anja Rohwer, Reduction of Employment Protection in Europe: A Comparative Fuzzy-Set Analysis, October 2009

2829 Rainald Borck and Martin Wimbersky, Political Economics of Higher Education Finance, October 2009

2830 Torfinn Harding and Frederick van der Ploeg, Is Norway's Bird-in-Hand Stabilization Fund Prudent Enough? Fiscal Reactions to Hydrocarbon Windfalls and Graying Populations, October 2009

2831 Klaus Wälde, Production Technologies in Stochastic Continuous Time Models, October 2009

2832 Biswa Bhattacharyay, Dennis Dlugosch, Benedikt Kolb, Kajal Lahiri, Irshat Mukhametov and Gernot Nerb, Early Warning System for Economic and Financial Risks in Kazakhstan, October 2009

2833 Jean-Claude Trichet, The ECB's Enhanced Credit Support, October 2009

2834 Hans Gersbach, Campaigns, Political Mobility, and Communication, October 2009

2835 Ansgar Belke, Gunther Schnabl and Holger Zemanek, Real Convergence, Capital Flows, and Competitiveness in Central and Eastern Europe, October 2009 
2836 Bruno S. Frey, Simon Luechinger and Alois Stutzer, The Life Satisfaction Approach to Environmental Valuation, October 2009

2837 Christoph Böhringer and Knut Einar Rosendahl, Green Serves the Dirtiest: On the Interaction between Black and Green Quotas, October 2009

2838 Katarina Keller, Panu Poutvaara and Andreas Wagener, Does Military Draft Discourage Enrollment in Higher Education? Evidence from OECD Countries, October 2009

2839 Giovanni Cespa and Xavier Vives, Dynamic Trading and Asset Prices: Keynes vs. Hayek, October 2009

2840 Jan Boone and Jan C. van Ours, Why is there a Spike in the Job Finding Rate at Benefit Exhaustion?, October 2009

2841 Andreas Knabe, Steffen Rätzel and Stephan L. Thomsen, Right-Wing Extremism and the Well-Being of Immigrants, October 2009

2842 Andrea Weber and Christine Zulehner, Competition and Gender Prejudice: Are Discriminatory Employers Doomed to Fail?, November 2009

2843 Hadi Salehi Esfahani, Kamiar Mohaddes and M. Hashem Pesaran, Oil Exports and the Iranian Economy, November 2009

2844 Ruediger Bachmann and Christian Bayer, Firm-Specific Productivity Risk over the Business Cycle: Facts and Aggregate Implications, November 2009

2845 Guglielmo Maria Caporale, Burcu Erdogan and Vladimir Kuzin, Testing for Convergence in Stock Markets: A Non-Linear Factor Approach, November 2009

2846 Michèle Belot and Jan Fidrmuc, Anthropometry of Love - Height and Gender Asymmetries in Interethnic Marriages, November 2009

2847 Volker Nitsch and Nikolaus Wolf, Tear Down this Wall: On the Persistence of Borders in Trade, November 2009

2848 Jan K. Brueckner and Stef Proost, Carve-Outs Under Airline Antitrust Immunity, November 2009

2849 Margarita Katsimi and Vassilis Sarantides, The Impact of Fiscal Policy on Profits, November 2009

2850 Scott Alan Carson, The Relationship between Stature and Insolation: Evidence from Soldiers and Prisoners, November 2009

2851 Horst Raff and Joachim Wagner, Intra-Industry Adjustment to Import Competition: Theory and Application to the German Clothing Industry, November 2009

2852 Erkki Koskela, Impacts of Labor Taxation with Perfectly and Imperfectly Competitive Labor Markets under Flexible Outsourcing, November 2009 
2853 Cletus C. Coughlin and Dennis Novy, Is the International Border Effect Larger than the Domestic Border Effect? Evidence from U.S. Trade, November 2009

2854 Johannes Becker and Clemens Fuest, Source versus Residence Based Taxation with International Mergers and Acquisitions, November 2009

2855 Andreas Hoffmann and Gunther Schnabl, A Vicious Cycle of Manias, Crashes and Asymmetric Policy Responses - An Overinvestment View, November 2009

2856 Xavier Vives, Strategic Supply Function Competition with Private Information, November 2009

2857 M. Hashem Pesaran and Paolo Zaffaroni, Optimality and Diversifiability of Mean Variance and Arbitrage Pricing Portfolios, November 2009

2858 Davide Sala, Philipp J.H. Schröder and Erdal Yalcin, Market Access through Bound Tariffs, November 2009

2859 Ben J. Heijdra and Pim Heijnen, Environmental Policy and the Macroeconomy under Shallow-Lake Dynamics, November 2009

2860 Enrico Spolaore, National Borders, Conflict and Peace, November 2009

2861 Nina Czernich, Oliver Falck, Tobias Kretschmer and Ludger Woessmann, Broadband Infrastructure and Economic Growth, December 2009

2862 Evžen Kočenda and Martin Vojtek, Default Predictors and Credit Scoring Models for Retail Banking, December 2009

2863 Christian Gollier and Martin L. Weitzman, How Should the Distant Future be Discounted when Discount Rates are Uncertain?, December 2009

2864 Tiberiu Dragu and Mattias Polborn, Terrorism Prevention and Electoral Accountability, December 2009

2865 Torfinn Harding and Beata Smarzynska Javorcik, A Touch of Sophistication: FDI and Unit Values of Exports, December 2009

2866 Matthias Dischinger and Nadine Riedel, There's no Place like Home: The Profitability Gap between Headquarters and their Foreign Subsidiaries, December 2009

2867 Andreas Haufler and Frank Stähler, Tax Competition in a Simple Model with Heterogeneous Firms: How Larger Markets Reduce Profit Taxes, December 2009

2868 Steinar Holden, Do Choices Affect Preferences? Some Doubts and New Evidence, December 2009

2869 Alberto Asquer, On the many Ways Europeanization Matters: The Implementation of the Water Reform in Italy (1994-2006), December 2009 